\title{
7o. Investigating EFL teachers' perceptions of teaching English proverbs in EFL classes: A cross-cultural study
}

\section{Fatma KİMSESİZ}

APA: Kimsesiz, F. (2021) Investigating EFL teachers' perceptions of teaching English proverbs in EFL classes: A cross-cultural study. RumeliDE Dil ve Edebiyat Araştırmaları Dergisi, (24), 11951210. DOI: 10.29000/rumelide.997593.

\begin{abstract}
Emerging from the experiences of a specific society, proverbs commonly mirror certain cultural signs of the traditions, beliefs, and values of that society. This appears as one of the ways of teaching the target culture through building intercultural connections in English as a foreign language (EFL) classes. Correspondingly, this study reserves two aims: First, to investigate the perceptions of Turkish EFL teachers on teaching English proverbs for intercultural relations and the frequency of using English proverbs in EFL classes and second, to examine the ideas of English native-speaker language teachers residing in Turkey about the intercultural role of learning and using proverbs in learning Turkish. To that end, 65 English teachers participated in a likert-scale pattern of two questionnaires and 4 native English lecturers were e-mail interviewed. The data collected from the participants is analysed and described related to the qualitative and quantitative research procedure of the instruments. The study revealed that for culture teaching in EFL classes, teachers favoured teaching proverbs and they believed that teaching proverbs was effective in improving learners' language skills, grammar and vocabulary learning in learning an L2. As a second finding, native English lecturers were also positive towards learning Turkish proverbs as cultural connectors. Hence, the study accentuates the realization that proverbs can be effectively employed in teaching culture and evoking cultural relations between native language and the target language, plus in improving L2 skills and studies.
\end{abstract}

Keywords: Intercultural relationship, proverbs, teaching English as a foreign language

\section{İngilizce öğretmenlerinin yabancı dil olarak İngilizce derslerinde İngilizce atasözlerinin öğretilmesine yönelik algılarının araştırılması: kültürlerarası bir çalışma}

Öz

Atasözleri, belirli bir toplumun deneyimlerinden oluşarak, genellikle belirli kültürel geleneklerin izlerini, inançlarını ve bu toplumun değerlerini yansıtır. Bu, yabancı dil olarak İngilizce öğretilen sınıflarda, kültürlerarası bağ kurma yoluyla hedef kültürü öğretme yollarından biri olarak ortaya çıkar. Dolayısıyla bu çalışma iki amacı barındırır: İlk olarak, kültürlerarası ilişkiler için İngilizce atasözlerini öğretme üzerine İngilizce öğretmenlerinin algılarını ve yabancı dil olarak İngilizce sınıflarında İngilizce atasözlerini kullanma frekanslarını araştırmak ve ikinci olarak, Türkçe atasözlerini kullanmada ve öğrenmede atasözlerinin kültürlerarası rolü hakkında Türkiye’de yaşamakta olan anadili İngilizce olan dil öğretmenlerinin fikirlerini incelemek. Bu amaçla, 65 İngilizce öğretmeni beşli likert-ölçeği düzeninde iki ankete katıldı ve ana dili İngilizce olan 4

Dr. Öğr. Üyesi, Kırşehir Ahi Evran Üniversitesi, Yabancı Diller Yüksekokulu, Mütercim Tercümanlık Bölümü (Kırşehir, Türkiye), fm.kmssz25@gmail.com, ORCID ID: 0ooo-0001-6758-7393 [Araştırma makalesi, Makale kayıt tarihi: 01.08.2021-kabul tarihi: 20.09.2021; DOI: 10.29000/rumelide.997593]

Adres $\mid$ Address

RumeliDE Dil ve Edebiyat Araştırmaları Dergisi Osmanağa Mahallesi, Mürver Çiçeği Sokak, No:14/8 Kadıköy - ISTANBUL / TÜRKIYE 34714 e-posta: editor@rumelide.com

RumeliDE Journal of Language and Literature Studies Osmanağa Mahallesi, Mürver Çiçeği Sokak, No:14/8

Kadıköy - ISTANBUL / TURKEY 34714 tel: +90 $5057958124,+902167730616$

e-mail: editor@rumelide.com,

phone: +90 505 7958124, +90 2167730616 
öğretmenle de e-mail görüşme yapıldı. Katılımcılardan toplanan veriler niteliksel ve niceliksel araştırma yöntemleriyle uyumlu olarak analiz edildi ve tanımlandı. Çalışma, yabancı dil olarak İngilizce öğretimi sınıflarında kültür öğretimi için öğretmenlerin atasözü öğretmeyi desteklediğini ve atasözlerini öğretmenin ikinci dil öğreniminde öğrencilerin dil yetenekleri, dilbilgisi ve kelime öğrenmeyi geliştirdiği konusunda etkili olduğuna inandıklarını ortaya çıkardı. 2. Bir bulgu olarak, anadili İngilizce olan öğretmenler kültürel bağlayıcı olarak atasözlerinin öğretilmesine olumlu yaklaşmışlardır. Bu nedenle, çalışma atasözlerinin kültürü öğretmede anadil ve hedef dil arasındaki kültürel bağı çağrıştırmada etkili bir şekilde kullanılabildiğini ve yabancı dil yeteneklerini ve çalışmalarını geliştirmede kullanılabileceğini ortaya çıkardı.

Anahtar kelimeler: Kültürlerarası ilişki, atasözleri, yabancı dil olarak İngilizce öğretimi

\section{Introduction}

A common strategy used to study the link between culture and language teaching is tracing through an associating line between L1 and L2. As highlighted by McKay (2003), culture has both linguistic and pedagogic impacts on L2 learning. In this sense, proverbs are widely considered to be a good way to promote an intercultural bridge in teaching an L2 (Byram, 1995; Ciccarelli, 1996; Richmond, 1987). As a mirror that reflects the elements of a whole society, culture is rated as "a dynamic, developmental, and ongoing process which engages the learner cognitively, behaviorally, and affectively" (Paige et. al., 2003, p. 177). Particularly for increasing learner comprehension in the target language (Sarıül \&Ashton-Hay, 2005; Tseng, 2002) and developing intercultural competence (Byram, 1995) exploring the target culture is essential. As underlined by Byram (1995), in language teaching, gaining insights in understanding links and distinctions in L1 and L2 is essential for developing a sound chain ring between these languages. This ring needs to be strengthened by adopting a variety of teaching strategies. Rather than presenting cultural facts, it will be better when culture is seen as an interpersonal process (Kramsch, 1993). Hence, language teachers need to be familiar with the cultural context of the target language they are teaching (Byram, 1994). In foreign language learning, learners should be familiar with culturally convenient ways to communicate effectively (Peterson \& Coltrane, 2003; Thanasoulas, 2001).

Phraseology, the study of phrases, concerns with all formulaic language and phraseological units covering proverbs and proverbial expressions, idioms and idiomatic expressions, and literary quotations (Granger \& Paquot, 2008; Mieder, 2004). Having been widely adopted in the field of Phraseology, Paremiology, the study of proverbs handle the issue more comprehensively concerning "anthropology, art, culture, folklore, literature, philology, religion, and sociology" (Mieder, 2004). Literally to define, a proverb is an irrevocable epigram that briefs the total event in a humoristic way (Taylor, 1996; Yurtbaşı, 1993) and acts as the largest judiciary at the time of the conversation (Boers, 2000). Moreover, proverbs have a metaphoric (Norrick, 2014) and objective illustration of philosophical truths (Baltacioğlu, 1994) with figurative characteristics and maintenance of metaphoric competence (Littlemore \& Low, 2006; Norrick, 1985). One of the most common characteristic of proverbs is that although they may carry a local origin, they have universal meaning in usage (Gözpınar, 2014). Some proverbs are rhymed as if they were a part of a poem (Batur, 2009). Even though proverbs are depicted with a variety of labels, an inclusive definition comes from Mieder (2004, p.39) who noted that "A proverb is a short, generally known sentence of the folk which contains wisdom, truth, morals, and traditional views in a metaphorical, fixed and memorable form, and which is handed down from generation to generation". As to the use of proverbs, it is worthwhile to state that they can be encountered in political rhetoric, in song lyrics, headlines in magazines and newspapers, book titles, advertising slogans, cartoon caption,

\footnotetext{
Adres $\mid$ Address

RumeliDE Dil ve Edebiyat Araştırmaları Dergisi $\quad$ RumeliDE Journal of Language and Literature Studies Osmanağa Mahallesi, Mürver Çiçeği Sokak, No:14/8 Osmanağa Mahallesi, Mürver Çiçeği Sokak, No:14/8 Kadıköy - ISTANBUL / TURKIYE 34714 Kadıköy - ISTANBUL / TURKEY 34714 e-posta: editor@rumelide.com e-mail: editor@rumelide.com, tel: +90 505 7958124, +90 2167730616 phone: +90 505 7958124, +90 2167730616
} 
greeting cards, frequently occurring in radio, TV, commercials, and on the internet (Mieder, 2004; Nippold et al, 2000). As a part of linguistic and social values of the cultural patterns, proverbs picture the customs and lifestyles of a nation's own existence and identity.

\section{Proverbs and culture in foreign language teaching}

The culture of a nation can be mirrored through several units that make up the total. Among those units, language is one of the most essential factors. In the light of a language, culture is reflected in its literature, linguistic forms, discourse, and other parameters that a language carries and all these figures may encapsulate the wisdom of the past, tradition, social and cultural values, world view, behavior, and tendencies of that nation (Gözpınar, 2014). In foreign language teaching, culture learning has been regarded so essential that in addition to other language skills, Larsen-Freeman (2001) regarded it as the fifth skill in language learning. According to Byram and Feng (2004), for culture learning, learners and teachers need to focus on experiential and experience of differences with a comparative approach. As remarked by Genç \& Bada (2005), culture learning can raise cultural awareness of foreign language learners related with both native and target societies. Due to the fact that culture is acknowledged as "the necessary context for language use" (Stern, 1992, p.205), teaching language without culture sounds unfeasible.

From the viewpoint of Byram (1994), foreign language teachers need to take on teaching foreign culture, hence; they need to analyze and experience both L1 and L2 cultures. It is claimed that it is essential for foreign language teachers to benefit from the culture of the target language as a distinct way to teach an L2 (Alptekin, 1993; Ulusoy, 2010). As explained by Palmer \& Brooks (2004, p.373) "if they [students] are thinking metaphorically, then they not only can understand experiences that have been depicted metaphorically but can also construct metaphors that reflect their own schematic experiences". In this sense, foreign language teachers should also be familiar with the speech acts and connotations in the target language (Thanasoulas, 2001). Notwithstanding that proverbs emerge from shared cultural wisdom (Norrick, 2014), they spring from community rules and ethics (Lemghari, 2017) and judgments made in different situations by the members of a society (Sarıgü \& Ashton- Hay, 2005). Because of the fact that proverbs are regarded as a rich heritage of collective thinking, experience, and value system of the society; they stand for traditional responses to repeated ethical problems verbally transmitting cultural values for generations with an oral history (Kurt, 1992). Embedding it in a cultural base, Norrick $(2014,23)$ states that proverbs can be described 'within their cultural matrix'. Their role in bearing 'folklore' and 'traditionality'(Norrick, 2014, 11) allows cross-cultural comparison in terms of intercultural transmission and translation, especially to establish a common ground between L1 and L2 (Mandziuk- Nizinska, 2020). In addition, highly equivalent interlingual proverbs coincide in carrying a similar message and actualizing identical parts of the linguistic world model. This makes the proverbs more memorable and clear in both languages (Mandziuk-Nizinska, 2020).

In culture teaching, proverbs enable the exploration of the values reflected in the proverbs of the target language that is learned (Sarıgül \& Ashton-Hay, 2005). Thus, it is important to know what specifically should be taught. Relatedly, learners should be able to notice culturally appropriate ways when addressing people, expressing gratitude, and making requests. Therefore, not only linguistic competence but also communicative competence should be improved when learning a foreign language. Proverbs are essential for understanding different spoken and written discourse (Litovkina, 2000) and for relating to concepts akin in learners' L1 when the nucleus of a proverb is literally covered (Collis, 1994). By linking proverbs to daily situations in language use, learners' understanding of the language in

\footnotetext{
Adres $\mid$ Address

RumeliDE Dil ve Edebiyat Araşturmaları Dergisi $\quad$ RumeliDE Journal of Language and Literature Studies Osmanağa Mahallesi, Mürver Çiçeği Sokak, No:14/8 $\quad$ Osmanağa Mahallesi, Mürver Çiçeği Sokak, No:14/8 Kadıköy - ISTANBUL / TÜRKIYE 34714 Kadıköy - ISTANBUL / TURKEY 34714 e-posta: editor@rumelide.com e-mail: editor@rumelide.com, tel: +90 505 7958124, +90 2167730616 phone: +90 505 7958124, +90 2167730616
} 
particular contexts can be facilitated (Ok, 2015). However, learners can get confused and misunderstand the interactions with each other when they are unable to understand the figurative language.

Few studies have focused on the effect of proverbs in the investigation of foreign language teaching and culture in Turkey. These studies generally focused on the primary role of proverbs as cultural ties between English and Turkish languages in learning EFL (Can, 2011; Gözpınar, 2014; Koçer \& Dinçer, 2011; Yağız \& Izadpanah, 2013). As prior research, Can (2011) investigated the perceptions of freshman ELT students on teaching English proverbs. The study proved positive results although most of them stated that cultural aspects of proverbs sounded interesting to them and yet did not have enough knowledge about English proverbs. Thus, the study concluded that ways to direct ELT students to focus on proverbs and to increase their awareness in language use can be promoted, benefitting from their knowledge of proverbs in L1 and reflect their knowledge of English proverbs into their own teaching. Carrying out a comparative study, Ok (2015) found out that learners found learning proverbs enjoyable and interesting as they explored and interpreted the same proverb in their native language rather than translating it in a form of one-to-one correspondence.

Aiming to investigate the ways that are adopted in teaching proverbs in EFL, Gözpınar (2014) discovered a positive effect on learning EFL related with the development of cultural learning, metaphorical understanding, and the development of effective interactive skills. Some of the participants focused on the cultural aspect of proverbs. Thus, by learning proverbs as a sign of cultural figures of that society, the learners can notice the similar and distinct patterns between the target culture and their native culture. To investigate whether specific L2 course books involve cultural patterns, several studies have been conducted (Can, 2011; Çakır, 2010; Çelik \& Erbay, 2013; Ulum \& Bada, 2016). These studies generally concluded that target culture needs to be taught as a step in building a cultural bridge between two languages. However, some L2 course books involve rare proverbs. Regarding this issue, teachers and learners feel the necessity to show more attention to the proverbs involved in the course books (Can, 2011; Çakır, 2010).

All things considered about the relation between proverbs and culture in foreign language teaching, the aim here is to investigate perceptions of EFL teachers in Turkey about teaching proverbs for their role in building an intercultural bridge between English and Turkish in EFL classes. To further the study, the following research questions were adopted:

1. What are the opinions and attitudes of English teachers towards the use, contribution, and role of using proverbs in teaching EFL?

2. How often do teachers of English use proverbs for teaching the target culture in EFL classes?

3. How do English native speakers living in Turkey feel about the cultural role of learning Turkish proverbs in both English and Turkish?

\section{Method}

\section{Design}

This study employs a mixed-method research design generating both qualitative and quantitative procedures. The quantitative aspect is descriptive and employs two questionnaires applied to English teachers. The questionnaires are adapted from Gözpınar's study on teaching English proverbs in EFL

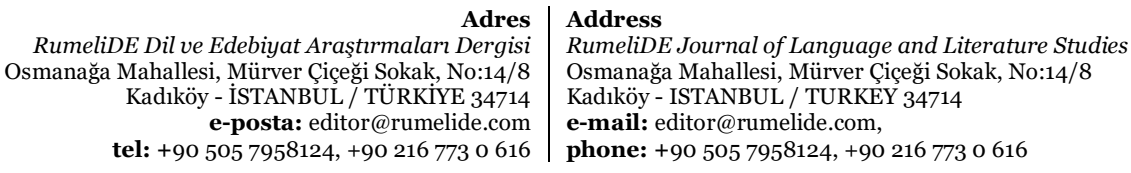


classes (2014). On the other hand, the qualitative part includes semi-structured e-mail interviews with four English native speakers teaching English and residing in Turkey.

\section{Participants}

\section{Teacher participants}

Sixty five teacher participants ( 54 females, 11 males) who teach English as a foreign language in Turkey participated voluntarily in the quantitative part of the study. The participants were selected through simple random sampling. Their ages range between $24-60.77 \%(\mathrm{~N}=50)$ of them were ELT graduates, $20 \%(\mathrm{~N}=13)$ were graduates of ELL and $3 \%(\mathrm{~N}=2)$ are graduates from some other departments. $17 \%$ $(\mathrm{N}=11)$ of them are teaching English at a primary school, 25\% $(\mathrm{N}=16)$ are teaching at secondary school, $35 \%(\mathrm{~N}=23)$ are teaching at high school, and $23 \%(\mathrm{~N}=15)$ are teaching English at higher education level in Turkey. The range of their experience year in teaching EFL is shown in Table 1 below.

Table 1. Experience year of teacher participants in teaching English

\begin{tabular}{lll}
\hline Experience year in teaching English & $\mathbf{N}$ & $\mathbf{\%}$ \\
\hline $1-4$ years & 3 & 5 \\
5-9 years & 14 & 22 \\
$10-14$ years & 28 & 43 \\
$15-19$ & 11 & 15 \\
20 and more & 9 & 14 \\
\hline
\end{tabular}

\section{Participants of the e-mail interview}

Four $(\mathrm{F}=2, \mathrm{M}=2)$ participants took part in an e-mail interview. They are native speakers of English and they have been living in Turkey for at least 5 years. Their ages range between $34-63$. Three of the participants are from The United States and one of them is from England. The participants have been teaching English at higher education levels in Turkey for more than 4 years.

\section{Instruments}

The first instrument is a pair questionnaires applied to 65 English teachers in Turkey. The questionnaires were adapted from Gözpınar's study in 2014 and the participants participated in the questionnaires via an online document survey link. The questionnaires are given in Appendix A and Appendix B. As described by Gözpınar (2014), initial piloting was carried out with five experts to be understandable in English for ensuring high reliability and validity.

The first questionnaire involves 16 items surveying the agreement of the participants on the statements. The second questionnaire surveys the frequency of using proverbs in EFL classes by the participants. These totally 26 items of the instrument were formed in the Likert scale that is the most commonly preferred scaling technique as it is simple, versatile, and reliable (Dörnyei, 2003). The instrument asks the respondents to indicate some demographic information about themselves and to click on their answers about their ideas and behaviors related with the role of proverbs in building an intercultural relationship between cultures and the frequency of their use of proverbs in teaching EFL to be indicated in a multiple-choice fashion.

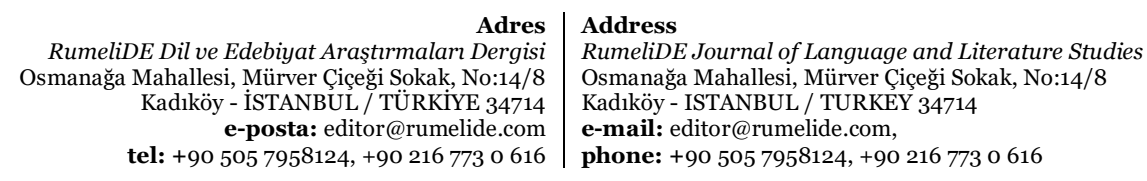


The second instrument employs a semi-structured e-mail interview that is based on computer-assisted communication (Linabary \& Hamel, 2017). The e-mail was held with 4 native speakers of English living in Turkey. Previously, 12 interviewees were contacted through e-mails requesting them to reply to three open-ended interview questions related with their ideas and approaches towards using proverbs and their role as cultural connectors between Turkish and English. However, 4 of them replied to the e-mail, expressing their ideas and feelings related with the interview questions. The e-mail interview questions are given in Appendix C.

\section{Procedure}

For the first phase of the study, 65 teachers of English participated in two online questionnaires formed through 'docs with google workspace' programme. The first questionnaire surveyed teachers' opinions and attitudes towards the use, contribution and the role of proverbs in teaching EFL. The second questionnaire surveyed the frequency of using English proverbs by the participants in EFL classes. Data were collected through the questionnaire from teacher participants who were sent links requesting them to participate in the questionnaire described above. The data obtained from the questionnaire was retabled and documented by the researcher. No names were placed on this survey. It has been assumed through the study that participants are familiar with the definition and role of proverbs in a language. For the next data collection procedure, 4 native speakers of English teaching English in Turkey were sent e-mails requesting them to reply the interview questions. Their answers were documented from the e-mail replies by the researcher.

\section{Data analysis}

The data of the questionnaire survey from English language teachers were collected through an online document form designed by the researcher and analysis of the questionnaire survey was conducted through the analytics of the 'docs with google workspace' programme for the related questionnaire. The data collected from the native speakers of English living in Turkey were documented and arranged in a question-answers pattern for each question by the researcher.

\section{Findings and results}

\section{What are the opinions and attitudes of English teachers towards the use, contribution, and role of using proverbs in teaching EFL?}

To find out EFL teachers' opinions and attitudes towards the use, contribution, and the role of using proverbs in teaching EFL, initially participants were asked to respond to 6 items based on a Likert scale. Regarding the ideas of the teacher participants about the roles of proverbs in teaching language skills, the responses are as follows:

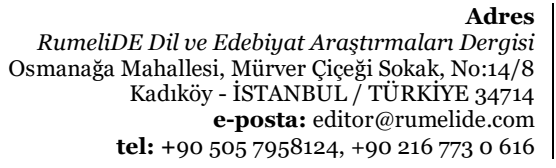

dres

RumeliDE Journal of Language and Literature Studies

Osmanağa Mahallesi, Mürver Çiçeği Sokak, No:14/8

Kadıköy - ISTANBUL / TURKEY 34714

e-mail: editor@rumelide.com,

phone: +90 5057958124 , +90 2167730616 
Table 2. Teachers' Responses about the Roles of Proverbs in Teaching Language Skills

\begin{tabular}{|c|c|c|c|c|c|c|}
\hline No & Statements & $\begin{array}{l}\text { Strongly } \\
\text { Agree }\end{array}$ & Agree & Neutral & Disagree & $\begin{array}{l}\text { Strongly } \\
\text { Disagree }\end{array}$ \\
\hline \multicolumn{7}{|c|}{ Percent \% } \\
\hline 1 & $\begin{array}{l}\text { Learning proverbs is integral to the overall } \\
\text { English language learning experience. }\end{array}$ & 25 & 57 & 13 & 5 & o \\
\hline 2 & $\begin{array}{l}\text { To communicate effectively in English, } \\
\text { you need to learn to use proverbs }\end{array}$ & 19 & 57 & 15 & 9 & o \\
\hline 3 & $\begin{array}{l}\text { Using proverbs in oral presentations will } \\
\text { make them more effective. }\end{array}$ & 37 & 53 & 5 & 5 & o \\
\hline 4 & $\begin{array}{l}\text { Knowing proverbs will improve reading } \\
\text { skills. }\end{array}$ & 29 & 59 & 6 & 6 & o \\
\hline 5 & $\begin{array}{l}\text { Using proverbs in written communication } \\
\text { will improve writing skills. }\end{array}$ & 32 & 43 & 20 & 5 & o \\
\hline 6 & $\begin{array}{l}\text { Understanding proverbs improves listening } \\
\text { comprehension. }\end{array}$ & 43 & 48 & 9 & o & o \\
\hline
\end{tabular}

Based on their opinion, as shown in Table 2 above, most of the teachers (item 1, 82\%, N=53) thought that learning proverbs is integral to the overall English language learning experience, however, a few participants (item 1, $5 \%, \mathrm{~N}=3$ ) disagree with this idea. Similarly, most of the teachers (item 2, $76 \%$, $\mathrm{N}=49$ ) feel that they need to learn how to use proverbs to communicate effectively in English and they agree with the idea that using proverbs in oral presentations will make them more effective (item 3, 90\%, $\mathrm{N}=58$ ). The majority of the teachers think that knowing proverbs will improve reading skills (item 4 , $80 \%, \mathrm{~N}=52$ ), and their writing skills will be improved by using proverbs in written communication (item $5,75 \%, N=48$ ). Finally, almost all of the teachers are positive with the idea that listening comprehension can be improved through understanding proverbs (item 6, 91\%, $\mathrm{N}=59$ ).

Secondly, regarding the perceptions of teachers on the literary aspects of proverbs and their role as a culture reflector, statistics are as follows based on a 6-item Likert scale:

Table 3. Teachers' perceptions on the literary aspects of proverbs and their role as culture reflector

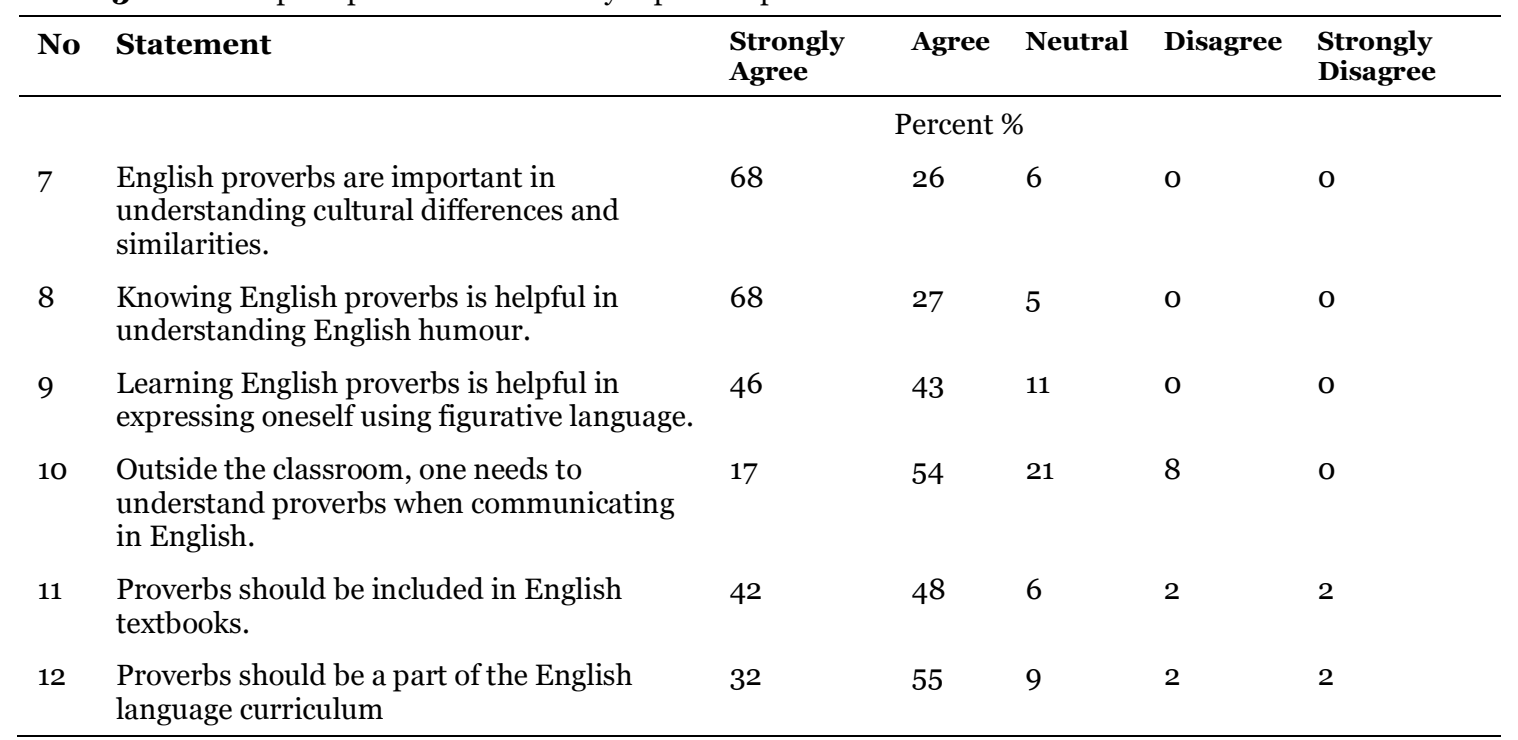

Adres
RumeliDE Dil ve Edebiyat Araşttrmaları Dergisi
Osmanağa Mahallesi, Mürver Çiçeği Sokak, No:14/8
Kadıköy - İSTANBUL / TÜRKIYE 34714
e-posta: editor@rumelide.com
tel: +90 505 7958124, +90 2167730616
Address

RumeliDE Journal of Language and Literature Studies

Osmanağa Mahallesi, Mürver Çiçeği Sokak, No:14/8

Kadıköy - ISTANBUL / TURKEY 34714

e-mail: editor@rumelide.com,

phone: +90 505 7958124, +90 216773 o 616 
Table 3 above displays teachers' perceptions on the literary aspects of proverbs and also their role as culture reflectors. Nearly all of the participants agreed upon the importance of using proverbs in understanding cultural differences and similarities (item $7,94 \%, \mathrm{~N}=61$ ) and its contribution to understanding English humor (item 8, 95\%, N=62). Most of the participants noted that learning English proverbs is helpful in expressing themselves using figurative language (item 9, 89\%, N=58) and that proverbs are important in outside communication (item $10,81 \%, \mathrm{~N}=53$ ). A great majority of the participants thought that proverbs should be included in course books as a part of the English language curriculum (item 11, 89\%, N=58) and they should be included in the English language teaching curriculum (item 12, 87\%, 57).

Regarding the teachers' knowledge about proverbs, their responses are as follows:

Table 4. Teachers' Knowledge about Proverbs

\begin{tabular}{|c|c|c|c|c|c|c|}
\hline No & Statement & $\begin{array}{l}\text { Strongly } \\
\text { Agree }\end{array}$ & Agree & Neutral & Disagree & $\begin{array}{l}\text { Strongly } \\
\text { Disagree }\end{array}$ \\
\hline \multicolumn{7}{|c|}{ Percent \% } \\
\hline 13 & I teach proverbs in my classroom & 19 & 44 & 26 & 9 & 2 \\
\hline 14 & $\begin{array}{l}\text { I know the semantic features of proverbs } \\
\text { (e.g. their themes, synonyms and antonyms, } \\
\text { etc.). }\end{array}$ & 14 & 49 & 23 & 11 & 3 \\
\hline 15 & $\begin{array}{l}\text { I understand the literary aspects of proverbs } \\
\text { (e.g. use of metaphors, rhyme etc.). }\end{array}$ & 17 & 57 & 20 & 6 & $\mathrm{o}$ \\
\hline 16 & $\begin{array}{l}\text { I understand the cultural aspects of English } \\
\text { proverbs. }\end{array}$ & 17 & 61 & 17 & 5 & $\mathrm{o}$ \\
\hline
\end{tabular}

Table 4 above reveals that more than half of the teachers admitted that they teach proverbs in their English classes (item 13, 63\%, N=41) and they know their semantic features (item 14, 63\%, N=41). They also revealed that they understand the literary (item $15,74 \%, \mathrm{~N}=48$ ) and cultural (item 16, 78\%, N=51) aspects of English proverbs.

\section{How often do teachers of English use proverbs for teaching the target culture in EFL classes?}

Regarding the frequency of the use of English proverbs in teaching EFL, their responses are displayed as follows:

Table 5. The Frequency of Teachers' Use of Proverbs in their EFL Classes

\begin{tabular}{|c|c|c|c|c|c|c|c|}
\hline No & Statement & & Always & Often & Sometimes & Rarely & Never \\
\hline \multicolumn{8}{|c|}{ Percent \% } \\
\hline 17 & \multicolumn{2}{|l|}{ I teach the importance of proverbs in communication. } & 8 & 29 & 43 & 18 & 2 \\
\hline 18 & \multicolumn{2}{|l|}{$\begin{array}{l}\text { I explain the poetic features of proverbs (e.g. rhyme, } \\
\text { alliteration, meter etc.) }\end{array}$} & 8 & 19 & 32 & 22 & 20 \\
\hline 19 & \multicolumn{2}{|l|}{$\begin{array}{l}\text { I teach English proverbs in comparison with Turkish } \\
\text { proverbs. }\end{array}$} & 15 & 32 & 34 & 14 & 5 \\
\hline 20 & \multicolumn{2}{|l|}{ I use English proverbs in culture teaching. } & 12 & 42 & 31 & 15 & o \\
\hline 21 & \multicolumn{2}{|l|}{ I use proverbs while teaching grammar. } & 2 & 15 & 37 & 31 & 15 \\
\hline & \begin{tabular}{r|r} 
Adres & \\
RumeliDE Dil ve Edebiyat Araştrrmaları Dergisi \\
Osmanağa Mahallesi, Mürver Çiçeği Sokak, No:14/8 \\
Kadıöy - İSTANBUL / TÜRKIYY 34714 \\
e-posta: editor@rumelide.com \\
tel: +90 505 7958124, +90 216 773 0 616
\end{tabular} & \multicolumn{6}{|c|}{$\begin{array}{l}\text { RumeliDE Journal of Language and Literature Studies } \\
\text { Osmanağa Mahallesi, Mürver Ciceği Sokak, No:14/8 } \\
\text { Kadlköy - ISTANBUL / TURKEY } 34714 \\
\text { e-mail: editor@ @rumelide.com, } \\
\text { phone: +90 505 7958124, +90 } 216773 \text { o } 616\end{array}$} \\
\hline
\end{tabular}




\begin{tabular}{lllllll}
22 & I use proverbs while teaching vocabulary. & 5 & 26 & 46 & 15 & 8 \\
23 & I use proverbs to teach listening skills. & 3 & 26 & 37 & 23 & 11 \\
24 & I use proverbs to teach writing skills. & 2 & 29 & 29 & 26 & 14 \\
25 & I use proverbs to teach speaking skills. & 5 & 37 & 31 & 21 & 6 \\
26 & I use proverbs to teach reading skills. & 3 & 40 & 31 & 18 & 8 \\
\hline
\end{tabular}

Table 5 above reveals the frequency of teachers' use of proverbs in their EFL classes. As shown, proverbs' frequency of use varies. Nearly half of the teachers stated that they sometimes focus on the importance of proverbs in communication (item 17, 43\%, N=28) and explain the poetic features of English proverbs (item 18, 32\%, N=21). Some of the teachers noted that they teach English proverbs concerning Turkish proverbs (item 19, 47\%, N=31). More than half of the teachers stated that in culture teaching, they apply to English proverbs (item 20,54\%, N=35). Some of the participants (\%37, N=24) admitted that they sometimes use proverbs while teaching grammar (item 21, 37\%, N=24). Adding the frequency of proverb use in classes, participants stated that they commonly use proverbs in improving vocabulary (item 22, $46 \%, \mathrm{~N}=30$ ), listening skills (item $23,37 \%, \mathrm{~N}=24$ ), in developing writing (item $24,31 \%, \mathrm{~N}=20$ ), speaking (item $25,42 \%, \mathrm{~N}=27$ ) and reading skills (item $26,43 \%, \mathrm{~N}=28$ ).

\section{How do English native speakers living in Turkey feel about the cultural role of proverbs in both English and Turkish?}

Based on the interview results, the researcher identified that participants agreed that proverbs are important for building an intercultural relationship when learning an L2. Related with the second research question, replies from the e-mail interview of the first question render their opinions about the importance of proverbs for building intercultural relationship when learning an L2.

As noted by $\mathrm{P} 1$, "it is good to cover them enough that the students will understand them if they see them in writing or hear them referenced somewhere, but in terms of being able to use them. However, when I hear proverbs used in conversation it is actually mostly by non-native speakers and the result is kind of like when older people try to use the new slang to fit in with kids. The nouns and verbs might be different but the concept is the same like to look at underlying norms and rules, but I usually mention to my students that most people are not throwing these phrases into casual conversation. They might have it written on a magnet on their refrigerator, or use one as a caption on some Instagram photo, but if they are talking to their friend online the night before big exam, they are not at all likely to write "okay I gotta go; early bird catches the worm."

On this sense, P2 stated that "learning of proverbs helps and provides another layer in language needs." Moreover, P3 agreed upon the view that proverbs are important for building intercultural relationship when learning and L2. $\mathrm{P} 4$ also noted that "proverbs are fun and enlightening, and though I cannot say how important they are, I believe that they enrich the language learning experience in many ways. They bring insight into the cultural nature of language, generally, and they show the universality of wisdom across cultures, our shared wisdom, what we have in common rather than what divides us. They are little pathways into culture, one could say, that support a better understanding of a new language as a whole."

The importance of proverbs has been a central issue related to the ideas of native speakers living in Turkey. To begin with, P1 stated that, proverbs may be useful particularly in written or oral form; however she stated that she didn't agree with its importance in usage, considered it as a kind of old

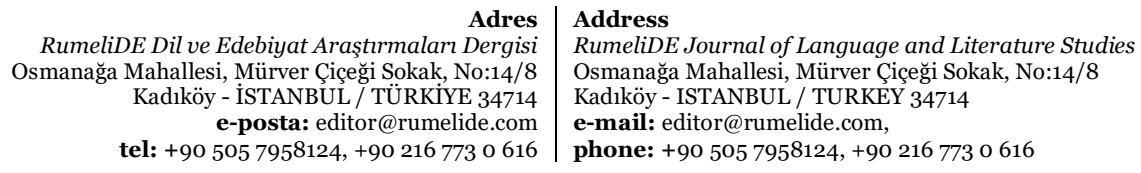


tradition common among old people, and claimed that it serves the purpose to be written on magnets or as captions. However, other participants noted that learning proverbs is needed ( $\left.\mathrm{P}_{2}\right)$ and important $\left(\mathrm{P}_{3}\right)$ for building an intercultural relationship in foreign language learning. Similarly, $\mathrm{P} 4$ acclaimed that proverbs enrich the language learning experience in many ways. Overall, excerpt 1 designated that participants are positive about the cultural role of proverbs in both English and Turkish. Although one of the participants declare that in case of communication with non-native speakers, it may not be necessary; other participants highlighted that proverbs are fun and entertaining pinning on their importance in the cultural nature of language. Referring to the abovementioned excerpt, as an outstanding viewpoint, what was expressed by $\mathrm{P} 4$ was that culturally, proverbs reflect what we have in common rather than what divides us.

For the necessity of learning Turkish proverbs in order to improve their oral skills, P1 noted that "it makes me a little crazy because I think there is more of a tendency in English to just say it instead of using a more ambiguous phrase. Whereas in Turkish, I feel like they cannot get by comfortably without knowing proverbs. (I cannot pick up on it yet to notice if people think that it is rude to say something directly instead of using the proverb. I hope it is not it is I hope they at least understand direct is really my only option if I can even manage that much. I know sometimes I will explain to my students "What you said is not wrong, but this is another one of those cases where there is going to be a difference between being technically right and sounding normal"'.

On the same question, $\mathrm{P} 4$ noted that "I have only been in Turkey three years and am still a beginner in Turkish, but I love learning proverbs from my native speaker friends and colleagues. I am a high level speaker of Russian, and also never tire of learning new Russian proverbs, as well. This harkens back to the nature of proverbs as keys to opening small doors into a higher understanding of the insightful nature of a culture when it comes to understanding the human experience. Though my language skills may not allow me to just share a proverb in a real-life language situation, such as on the street here in Ankara, I put such proverbs into my language notebooks and allow myself to feel a little thrum of pleasure and confidence in that I am one tiny step closer to a higher understanding of Turkish".

For the second question that examined participants' need for learning Turkish proverbs in order to improve their oral skill, they favored learning Turkish proverbs. As clarified by P1, she needs to grasp what people mean when they use proverbs. Another viewpoint that is integral to the part of language and culture was accounted by $\mathrm{P} 4$ who exemplified the nature of proverbs as keys that open doors for a better understanding of the nature of a culture. He also noted that he feels pleased and confident when he gets to know what an encountered proverb deeply means.

For the ideas of participants about interlingual proverbs and feeling warm towards target culture, P1 noted that "it is good for that and we go over it that way in my class sometimes. If we are talking about daily situations and there is a proverb that would apply to the situation, I will usually tell them what it is and explain it and about half the time or more they realize there is a phrase with similar meaning in Turkish". Moreover, $\mathrm{P}_{3}$ stated that such proverbs make her feel warm towards Turkish language. Then she feels that we have much things in common to share.

On the same issue, $\mathrm{P} 4$ replied that "I believe that similarities between the cultures should be exploited in a positive way. Anything that brings us closer to our shared humanity supports the reasons why we learn languages. If the proverbs are similar, but use different metaphorical language units, for example, they serve to show how the languages and culture may differ in expressing ideas, but how

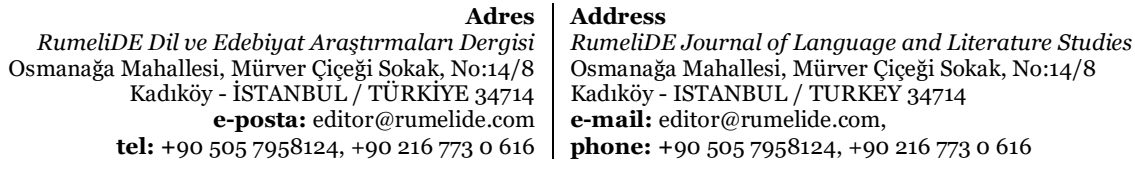


the ideas are essentially the same, proving that common ground exists, no matter how it has been expressed throughout time in various cultures".

As indicated by the abovementioned excerpts, participants feel that interlingual proverbs approximate them a step further to each other's language. As exemplified by P1, they may encounter some common proverbs with a similar meaning in both languages, and this makes them feel good. $\mathrm{P}_{3}$ stated that he feels warm toward the Turkish language and feels that we have common things to share. In a similar vein, $\mathrm{P}_{4}$ stated that there is a common ground in the way ideas are expressed no matter how much change in time they have been exposed to. The central issue addressed here is that interlingual factors between two languages may bring the members of those communities closer and prove that common grounds may exist culturally.

\section{Discussion}

The present study attempts to crystallise connecting role of proverbs for cultural awareness in learning and teaching a foreign language. It has been highlighted in many cultural and linguistic studies that language and culture are inevitably intertwined (Alptekin, 1993, 2002; Byram, 1994; Peterson \& Coltrane, 2003; Scarino, 2010). Although there has been less previous evidence for the cultural impact of proverbs in teaching EFL in Turkey, insights drawn from scholarly literature are supplemented with those from studies in comparatively presenting proverbs for the sake of motivating learners in learning L2 (Koçer \& Dinçer, 2011; Yağız \& Izadpanah, 2013). Prior research also focused on the prime role of language teachers to sketch best ways to include proverbs in the language teaching process as a cultural attachment (Can, 2011; Genç \& Bada, 2005; Gözpınar, 2014; Kuru Gönen \& Sağlam, 2012; Moein, Khosravi \& Yazdani, 2014). Similar to the current research, Kuru Gönen \& Sağlam (2012) concluded that teachers are commonly aware of the importance of teaching and integrating culture in EFL classes, however, they need to consider the curricular considerations which commonly lack cultural focus. In this study, it has been found out that the majority of the teachers who took the questionnaire agreed that proverbs are important for a better understanding of the English language culture, especially in literal ways and they revealed that they know proverbs and teach them by associating them with related themes in English classes. They also revealed that they use proverbs for a variety of reasons such as focusing on cultural integrity, vocabulary teaching, and communicative reasons. These results confirmed the study by Koçer \& Dinçer (2011) designating that culture-integrated courses can enable teachers to maintain imaginative ideas and to get students to have broad visions about the world. Similar results were later discovered by Can (2011) with student-teachers. She found out that most of the EFL student-teachers that participated in their study had positive attitudes towards learning and teaching English proverbs revealing that their knowledge of proverbs was insufficient since they did not encounter them in English classes at high school.

Correspondingly, prior research generally outlined that English teachers should consider proverbs in teaching culture in a comparative way. Gözpınar (2014) proffered that English teachers need to collaborate for investigating the best ways to teach proverbial wisdom and proverbs especially to teach moral values in a more understandable way concluding that teaching proverbs will help for improving the multicultural perspective of the students. As a matter of fact, these findings point out the advantages and practicability of teaching proverbs as cultural connectors both in L1 and L2, virtually in teaching L2.

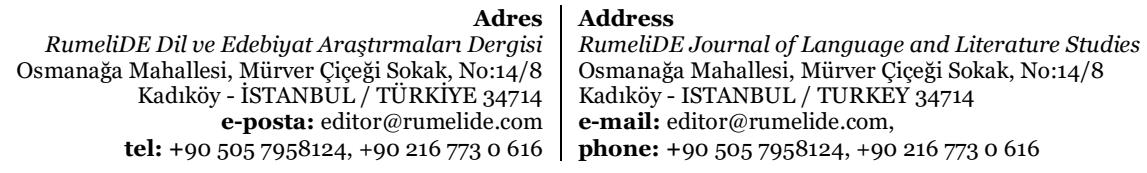

Adres
RumeliDE Dil ve Edebiyat Araştırmaları Dergisi

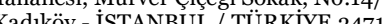
tel: +90 505 7958124, +902167730616 
Another conclusion that can be drawn from this study is by native speakers who were e-mail interviewed. They expressed that proverbs are useful and necessary when learning a foreign language and they can be entertaining in noticing the cultural nature of the languages as they reflect our common values rather than our distinctions. Hence, as outlined by Yağız \& Izadpanah (2013), it is better for language teachers to equip themselves with the knowledge of the target culture to make learners familiar with cultural differences and have high esteem for their own culture in order to forward language learning process. Findings in this study are also consistent with the results of Moein, Khosravi \& Yazdani (2014), who concluded that teaching proverbs should be considered more seriously, by observing the cultural differences and presenting them in a comparative way for more effective teaching. Reviewing all these, it is possible to make a point for connecting these two research areas: English teachers commonly use and teach proverbs of the target language in teaching EFL and native English teachers find learning the proverbs of the target culture useful for the same reason; to build a cultural bridge between two languages when learning an L2.

\section{Conclusion and pedagogical implications}

This study was conducted first, to investigate the perceptions of Turkish EFL teachers' on teaching English proverbs for intercultural relations; and second, to examine the ideas of native English speakers residing in Turkey about the intercultural role of employing proverbs in L2 learning. For this aim, 65 English teachers in Turkey were applied two questionnaires designed with a Likert scale through an online document form and the description of the data was analyzed quantitatively. Next, 4 native speakers living in Turkey were e-mail interviewed. The data were documented and interpreted from the e-mail replies by the researcher. In conclusion, the current study yielded bounding results in terms of involving proverbs as cultural connectors. The results showed that teachers are generally in favor of the use of proverbs as part of culture teaching in EFL classes and they believe that teaching proverbs can enhance language skills, vocabulary teaching, and improving grammar. Another conclusion drawn from this study is that native English speakers living in Turkey also feel the necessity for exploring the common grounds in using proverbs due to their cultural role in building familiarity and connection in both languages.

Thus, in the light of these findings and the studies discussed previously, teaching and learning proverbs of the target language is suggested in order to make learners feel a sense of cultural relationship and affinity. They need to feel that a foreign language is not something far beyond our windows opening for life, rather it's something with common beliefs and experiences that belong to all humanity. Then, their knowledge can be more significant and meaningful.

\section{References}

Aksoy, O. A. (1998). Dictionary of Proverbs and Idioms. Istanbul: Inkılap, 1998.

Alptekin, C. (1993). 'Target-Language Culture in EFL Materials'. ELT Journal. Vol. 47.

Baltacıolu, H. (1994). Türke doğru. Ankara: AKM.

Batur, S. (2009). Açılklama ve öyküleriyle Türk atasözleri. (2. Baskı). İstanbul: Altın Kitaplar.

Boers, F. (2000). Metaphor awareness and vocabulary retention. Applied Linguistics, 21, 553-571.

Byram, M. (1994). Teaching and Learning Language and Culture. Great Britain: WBC. Fransisco: Jossey-Bass Publications.

Byram, M. (1995). Foreign language teaching and intercultural citizenship. Iranian Journal of Language Teaching Research 1(3), 53-62.

\footnotetext{
RumeliDE Dil ve Edebiyat Araştırmaları Dergisi Osmanağa Mahallesi, Mürver Çiçeği Sokak, No:14/8 Kadıköy - ISTANBUL / TÜRKIYE 34714 e-posta: editor@rumelide.com tel: +90 505 7958124, +902167730616

Address

RumeliDE Journal of Language and Literature Studies

Osmanağa Mahallesi, Mürver Çiçeği Sokak, No:14/8

Kadıköy - ISTANBUL / TURKEY 34714

e-mail: editor@rumelide.com,

phone: +90 505 7958124, +90 2167730616
} 
Byram, M., \& Feng, A. (2004). Culture and language learning: teaching, research and scholarship. Language teaching., 37(3), 149-168.

Can, N. (2011). A proverb learned is a proverb earned, MA. Thesis, METU, Ankara.

Ciccarelli, A. (1996). Teaching culture through language: Suggestions for the Italian language class. Italica, 73(4), 563-576.

Çakır, İ. (2010). The frequency of culture-specific elements in the ELT coursebooks at elementary schools in Turkey. Novitas-ROYAL (Research on Youth and Language), 4(2), 182-189.

Çelik, S., \& Erbay, Ş. (2013). Cultural Perspectives of Turkish ELT Coursebooks: Do Standardized Teaching Texts Incorporate Intercultural Features?. Education and Science, 38(167), 336-351.

Dörnyei, Z. (2003). Questionnaire in second language research: Construction, administration, and processing. Mahwah, NJ: Lawrence Erlbaum Associates.

Gözpınar, H. (2014). The role of proverbs in forming intercultural awareness (on the basis of teaching English, Georgian and Turkish languages). Unpublished Doctoral Dissertation, Ivane Javakhishvili Tbilisi State University.

Granger, S., \& Paquot, M. (2008). Disentangling the phraseological web. In S. Granger \& F. Meunier (Eds.), Phraseology: An interdisciplinary perspective (pp. 27-51). Amsterdam: John Benjamins.

Koçer, Ö., \& Dinçer, A. (2011). The Effect of Culture Integrated Language Courses on Foreign Language Education. Online Submission, 8(3), 257-263.

Kramsch, C. (1993). Context and Culture in Language Teaching. Oxford: Oxford University Press.

Kurt, İ. (1992). Türk Atasözlerinde Psikolojik Bir Yaklaşım. Mas Matbaacılık. Ankara.

Kuru Gönen, İ., \& Sağlam, S. (2012). Teaching culture in the FL classroom: teachers' perspectives. International Journal of Global Education, 1(3).

Lemghari, E. (2017). Conceptual metaphors as motivation for proverbs lexical polysemy. International journal of language and linguistics. 5(3), 57-70. doi: 10.11648/j.ijll.20170503.11.

Linabary, R. J., \& Hamel, A. S. (2017). "Feminist online interviewing: ongoing issues of power, resistance and reflexivity in practice." Feminist Review No:115, ss. 97-113.

Litovkina, A. (2000). A Proverb a Day Keeps Boredom Away. Szekszárd-Pécs: IPF- Könyvek.

Littlemore, J., \& Low, G. (2006). Figurative thinking and foreign language learning. New York, NY: Palgrave Macmillan.

Mandziuk-Nizińska, J. (2020). To translate, or not to translate: A cognitive linguistic analysis of selected English and Polish proverbs.

McKay, S. L. (2003). The Cultural Basis of Teaching English as an International Language. Online Documents at URL http://www.tesol.org/pubs/articles/2003/tm13-4-01.html.

Mieder, W. (2004). Proverbs - A Handbook. Westport, CT; Greenwood Press.

Moein, B., Khosravi, R., \& Yazdani, H. (2014). The Role of Cross-linguistic Experience on English Idiom and Proverb Comprehension: A Case of Iranian Turkish Learners of English as a Foreign and Third Language. Theory \& Practice in Language Studies, 4(5).

Nippold, M. A., Allen, M. M., \& Kirsch, D. I. (2000). "How adolescents unfamiliar proverbs: The role of top-down and bottom-up processes." Journal of Speech, Language, and Hearing Research 43:621630.

Norrick, N.R. (1985). How Proverbs Mean: Semantic Studies in English Proverbs. Amsterdam: Mouton.

Norrick, N. R. (2014). Subject area, terminology, proverb definitions, proverb features". Introduction to Paremiology, edited by Hrisztalina Hrisztova-Gotthardt and Melita Aleksa Varga, Warsaw, Poland: De Gruyter Open Poland, 2015, pp. 7-27. https://doi.org/10.2478/9783110410167.1.

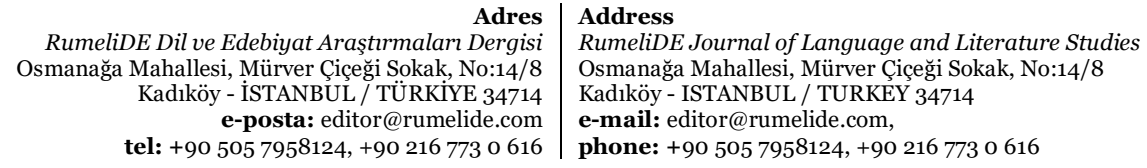


Ok, S. (2015). Reflections of ELT students on learning proverbs, International Journal of Language Academy, 3-4, 251-269.

Paige, R.M., Jorstad, H.L., Siaya, L., Klein, F., \& Colby, J. (2003). Culture learning in language education: A review of literature. In L Lange \& R. M. Paige (Eds.), Culture as the core (pp. 173237). Greenwich, CT:Information Age Publishing.

Palmer, B. C., \& Brooks, M. A. (2004). Reading until the cows come home: Figurative language and reading comprehension. Journal of Adolescent and Adult Literacy, 47, 370-379.

Peterson, E., \& Coltrane, B. (2003). Culture in Second Language Teaching. ERIC Clearinghouse on Languages and Linguistics, EDO-FL-03-09.

Richmond, E. B. (1987). Utilizing proverbs as a focal point to cultural awareness and communicative competence: Illustrations from Africa. Foreign Language Annals, 20(3), 213-216.

Sarigul, E., \& Ashton-Hay, S. (2005). Culture and English Language Teaching: Raising Awareness. In Proceedings 9th International INGED (Turkish English Education Association) Conference "New Horizons in ELT", Economics and Technical University, Ankara Turkey.

Taylor, A. (1996). Problems in the study of proverbs. De Proverbio, An Electronic Journal of International Proverb Studies, Vol. 2, No. 2: 1-17. ISSN 1323-4633.

Thanasoulas, D. (2001). The importance of teaching culture in the foreign language classroom. Radical pedagogy, 3(3), 1-25.

Tseng, Y.-H. (2002). A Lesson in Culture. ELT, 56, 11-21.

Ulum, Ö. G., \& Bada, E. (2016). Cultural elements in EFL Course books, Gaziantep University Journal of Social Sciences 15(1): 15-26.

Ulusoy, A. E. (2010). Atasözü neydi, ne oldu? [What was, and what now is, a proverb]. Milli folklor, 22(88), 5-15.

Yağiz, O., \& Izadpanah, S. (2013). Language, Culture, Idioms, and Their Relationship with the Foreign Language. Journal of Language Teaching \& Research, 4(5).

Yurtbaşı, M. (1993). A Dictionary of Turkish Proverbs, Ankara: Turkish Daily News.

\title{
Appendix A
}

\author{
Item Statements \\ Strongly Agree Neutral Disagree Strongly \\ Agree Disagree \\ Item Learning proverbs is integral to the \\ 1 overall English language learning \\ experience. \\ Item To communicate effectively in English, \\ 2 you need to learn to use proverbs \\ Item Using proverbs in oral presentations \\ 3 will make them more effective. \\ Item Knowing proverbs will improve reading \\ 4 skills. \\ Item Using proverbs in written \\ $5 \quad$ communication will improve writing \\ skills. \\ Item Understanding proverbs improves \\ 6 listening comprehension. \\ Item English proverbs are important in \\ 7 understanding cultural differences and \\ similarities.

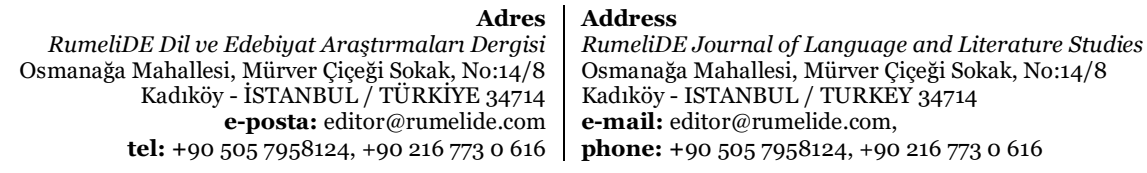


Item Knowing English proverbs is helpful in 8 understanding English humour.

Item Learning English proverbs is helpful in 9 expressing oneself using figurative language.

Item Outside the classroom, one needs to

9 understand proverbs when communicating in English.

Item Proverbs should be included in English 10 textbooks.

Item Proverbs should be a part of the

11 English language curriculum

Item English proverbs are important in

12 understanding cultural differences and similarities.

Item I teach proverbs in my classroom

13

Item I know the semantic features of

14 proverbs (e.g. their themes, synonyms and antonyms, etc.).

Item I understand the literary aspects of 15 proverbs (e.g. use of metaphors, rhyme etc.).

Item I understand the cultural aspects of 16 English proverbs.

\section{Appendix B}

\section{Item Statements}

Item I teach the importance of proverbs in 17 communication.

Item I explain the poetic features of proverbs (e.g. 18 rhyme, alliteration, meter etc.)

Item I teach English proverbs in comparison with 19 Turkish proverbs.

Item I use English proverbs in culture teaching. 20

Item I use proverbs while teaching grammar.

21

Item I use proverbs while teaching vocabulary.

22

Item I use proverbs to teach listening skills.

23

Item I use proverbs to teach writing skills.

24

Item I use proverbs to teach speaking skills.

25

Item I use proverbs to teach reading skills. 26

\section{Always Often Sometimes Rarely Never}

Adre

RumeliDE Dil ve Edebiyat Araştırmaları Dergisi Osmanağa Mahallesi, Mürver Çiçeği Sokak, No:14/8 Kadıköy - İSTANBUL / TÜRKIYE 34714 e-posta: editor@rumelide.com tel: +90 $5057958124,+902167730616$
Address

RumeliDE Journal of Language and Literature Studies Osmanağa Mahallesi, Mürver Çiçeği Sokak, No:14/8

Kadıköy - ISTANBUL / TURKEY 34714

e-mail: editor@rumelide.com,

phone: +90 5057958124 , +90 2167730616 
1210 / RumeliDE Journal of Language and Literature Studies 2021.24 (September)

Investigating EFL teachers' perceptions of teaching English proverbs in EFL classes: A cross-cultural study / F. Kimsesiz (pp. 1195-1210)

\section{Appendix C}

\section{The e-mail interview questions with the native speaker participants}

1. Do you think that proverbs are important for building intercultural relationship when learning an L2? If yes, in what ways do you think so?

2. Do you find it necessary to learn Turkish proverbs in order to improve your speaking or listening skills in Turkish? If yes, how do you learn them?

1. Do you feel that proverbs that are akin in meaning and that apply to the same situation in both L1 and L2 enable learning them? If yes, do they make you feel a warm relationship with Turkish language? How can you evaluate it?

RumeliDE Dil ve Edebiyat Araştırmaları Dergisi Osmanağa Mahallesi, Mürver Çiçeği Sokak, No:14/8 Kadıköy - ÍSTANBUL / TÜRKIYE 34714 e-posta: editor@rumelide.com tel: +90 $5057958124,+902167730616$
Address

RumeliDE Journal of Language and Literature Studies Osmanağa Mahallesi, Mürver Çiçeği Sokak, No:14/8

Kadıköy - ISTANBUL / TURKEY 34714

e-mail: editor@rumelide.com

phone: +90 505 7958124, +90 2167730616 